\title{
PERUSAKAN LINGKUNGAN SEBAGAI TINDAK PIDANA TERORISME
}

\author{
Rachman Maulana Kafrawi \\ Program Doktor Ilmu Hukum Universitas Airlangga \\ Kampus B Unair, Jl. Dharmawangsa Dalam Selatan, Surabaya \\ E-mail : rachmanmaulana778@gmail.com
}

\begin{abstract}
This research aims to identify whether the environmental destruction could be considered as terrorism and to identify why the person who damaged the environmental should be considered as a terrorist. The conclusion of this research indicates a concept which views that the person who did enviromental destruction as terrorism. This concept is textual elaboration which is contained in section 10 Law No. 15, 2003 about the eradication of the terrorism. The crime for environmental destructions which are catagorized as terrorism are as follows: The impacts of the environmental destruction and pollution exceed Baku Mutu Lingkungan Hidup (BMLH), the poisonous chemicals release in the public areas (as happened during internal armed conflict in suriah on March 2011), there are bulk of victims, and it harms and damages the strategical vital objects. Based on those criterion, the environmental destruction is considered as equal as terrorism, because they are catagorized as a crime againts humanity. The environmental destruction happens because of low obedience and awareness of people to protect and to save the environment and it could be indicator that the law enforcement for environmental protection and management has not gone well yet. Based on this concept, it is expected that the responsibility and commitment of Indonesia could be achieved in order to ensure the protection and fulfillment of the environment and human rights and to reach the aims of environmental justice.
\end{abstract}

Keywords: Environmental Destruction, Terrorism, Human Right

\begin{abstract}
Abstrak
Penelitian ini bertujuan untuk mengidentifikasi apakah perusakan lingkungan dapat dianggap sebagai terorisme dan untuk mengidentifikasi mengapa orang yang merusak lingkungan harus dianggap sebagai teroris. Kesimpulan dari penelitian ini menunjukkan konsep yang memandang bahwa orang yang melakukan perusakan lingkungan sebagai terorisme. Konsep ini merupakan penjabaran teks yang terkandung dalam pasal 10 UU No. 15 Tahun 2003 tentang Pemberantasan Terorisme. Kejahatan atas kerusakan lingkungan yang dikategorikan sebagai terorisme adalah sebagai berikut: Dampak kerusakan lingkungan dan polusi melebihi Baku Mutu Lingkungan Hidup (BMLH), pelepasan bahan kimia beracun di area publik (seperti yang terjadi selama konflik bersenjata internal di suriah pada bulan Maret 2011), ada banyak korban, dan itu membahayakan dan merusak benda-benda vital yang strategis. Berdasarkan kriteria tersebut, perusakan lingkungan dianggap sama dengan terorisme, karena mereka dikategorikan sebagai kejahatan terhadap kemanusiaan. Kerusakan lingkungan terjadi
\end{abstract}


karena rendahnya kepatuhan dan kesadaran masyarakat untuk melindungi dan menyelamatkan lingkungan dan bisa menjadi indikator bahwa penegakan hukum untuk perlindungan dan pengelolaan lingkungan belum berjalan dengan baik. Berdasarkan konsep ini, diharapkan bahwa tanggung jawab dan komitmen Indonesia dapat dicapai untuk memastikan perlindungan dan pemenuhan lingkungan dan hak asasi manusia dan untuk mencapai tujuan keadilan lingkungan.

\section{Kata kunci: Perusakan Lingkungan, Terorisme, Hak Asasi Manusia}

\section{A. PENDAHULUAN}

Istilah lingkungan hidup dalam bahasa Inggris disebut dengan environment, dalam bahasa Belanda desebut dengan millieu dan dalam bahasa Prancis disebut i'environment. Lingkungan hidup merupakan suatu tempat dimana di dalamnya terdapat makhluk hidup dan benda mati, yang kesemuanya itu berada dalam satu kesatuan. Lingkungan hidup juga sangat mempengaruhi kelangsungan hidup dan kesejahteraan manusia serta makhluk hidup lainnya. ${ }^{1}$ Dewasa ini kerusakan lingkungan bukanlah merupakan kasus yang ganjil lagi. Banyaknya masalah lingkungan yaitu illegal logging, illegal fishing, pengerukan tambang dan mineral, global warming, banjir, longsor, dan yang paling mengerikan adalah kebakaran hutan di negeri ini. Kerusakan lingkungan yang disebabkan ulah manusia tidak dapat dilihat sebagai kerusakan struktur fisik alam dan lingkungan saja, tetapi menjelaskan struktur kerusakan lebih dalam dan lebih kompleks.

Kasus kebakaran hutan yang baru ini menghanguskan ribuan hektar hutan Indonesia sudah memberikan bencana besar untuk saat ini maupun pada masa depan. Entah dinamai apa hajatan rutin pencemaran asap dari kebakaran hutan yang tak kunjung selesai dan selalu menyesakkan dada rakyat di Indonesia Raya ini. Mulai yang benar-benar sesak akibat dipaksa menghirup asap tersebut sampai yang akhirnya sesak karena begitu geramnya melihat realita lemahnya eksistensi pemerintah "untuk melindungi segenap bangsa Indonesia dan seluruh tumpah darah Indonesia dan untuk memajukan kesejahteraan umum, mencerdaskan kehidupan bangsa dan ikut melaksanakan ketertiban dunia". Demikianlah kiranya tujuan diadakannya negara Indonesia ini. Tapi, Semampu apa negara ini dalam melindungi segenap bangsa dan tumpah darahnya jika melindungi hak bernafas saja ia tidak mampu.

Lebih jauh, perusakan lingkungan dengan pembakaran hutan yang menimbulkan asap ini harusnya dipandang sebagai bentuk kejahatan terorisme. Sebagaimana dalam pasal 10 Perpu Nomor 1 Tahun 2002 tentang Pemberantasan Tindak Pidana Terorisme yang disahkan menjadi Undang-Undang melalui Undang-Undang No. 15 Tahun 2003, bahwa:

Dipidana dengan pidana yang sama dengan pidana sebagaimana dimaksud dalam pasal 6, setiap orang yang dengan sengaja menggunakan senjata kimia, senjata biologis, radiologi, mikroorganisme, radioaktif atau komponennya, sehingga menimbulkan

\footnotetext{
${ }^{1}$ Sodikin, Penegakan Hukum Lingkungan Tinjauan Atas Undang-Undang Nomor 23 Tahun 1997, Djembatan, Jakarta: 2003, hlm. 1.
} 
susasana teror, atau rasa takut terhadap orang secara meluas, menimbulkan korban yang bersifat massal, membahayakan terhadap kesehatan, terjadi kekacauan terhadap kehidupan, keamanan dan hak-hak orang, atau terjadi kerusakan, kehancuran terhadap objek-objek vital strategis, lingkungan hidup, fasilitas publik, atau fasilitas internasional. $^{2}$

Pembakaran hutan tersebut kandungannya tak kurang dari Sulfur Oksida (menyebabkan iritasi sampai peradangan saluran pernafasan), Karbon Monoksida (menghambat pasokan oksigen ke otak), Formaldehide (menyebabkan iritasi pada membran mukosa), Akrolein (merusak pembuluh darah), Benzena (karsinogen/ pemicu kanker) dan Nitrogen Oksida (mengganggu sitem saraf dan menyebabkan pembengkakan paru-paru). ${ }^{3}$ Berdasarkan latar belakang yang telah di uraikan di atas, maka dapat dirumuskan isu hukum dan permasalahan sebagai berikut : a) Apakah perusakan lingkungan dapat dipandang sebagai tindak pidana terorisme? dan b) Mengapa perusakan lingkungan perlu dipandang sebagai tindak pidana terorisme?

\section{B. PEMBAHASAN}

\section{Relevansi Perusakan Lingkungan Dipandang sebagai Tindak Pidana Terorisme} a. Esensi Perusakan Lingkungan Hidup

Menurut Pasal 1 Angka 16 Undang-Undang Nomor 32 Tahun 2009 tentang Perlindungan dan Pengelolaan Lingkungan Hidup "Perusakan lingkungan adalah tindakan orang yang menimbulkan perubahan langsung atau tidak langsung terhadap sifat fisik, kimia dan/atau hayati lingkungan hidup sehingga melampaui kriteria baku kerusakan lingkungan hidup". 4 Baku Mutu Lingkungan Hidup yang selanjutnya disingkat BMLH adalah ukuran batas atau kadar makhluk hiudp, zat, energi, atau komponen yang ada atau harus ada dan/atau unsur pencemar yang ditenggang keberadaannya dalam suatu sumber daya tertentu sebagai unsur suatu lingkungan hidup. ${ }^{5}$ Artinya, nilai ambang batas yang merupakan batas-batas daya dukung, daya tenggang dan daya toleransi atau kemampuan lingkungan.

Pengertian daya dukung lingkungan, daya toleransi lingkungan, dan daya tenggang lingkungan, yang dalam istilah asing disebut "Carrying capacity", adalah kemampuan lingkungan hidup untuk mendukung perikehidupan manusia, makhluk hidup lain, dan keseimbangan antara keduanya. ${ }^{6}$ Berdasarkan Pasal 20 Ayat 2 UUPPLH, BMLH berfungsi untuk menentukan terjadinya pencemaran. Baku Mutu Lingkungan Hidup meliputi: a) Baku Mutu Air; b) Baku Mutu Air Limbah; c) Baku Mutu Air Laut; d) Baku Mutu Udara Ambien; e) Baku Mutu Udara Emisi; f) Baku

\footnotetext{
${ }^{2}$ Pasal 10 Undang-Undang Nomor 15 Tahun 2003 tentang Penetapan Peraturan Pemerintah Pengganti UndangUndang Nomor 1 Tahun 2002 tentang Pemberantasan Tindak Pidana Terorisme.

${ }^{3}$ Fikri Faisal,et.al, "Dampak Asap Kebakaran Hutan pada Pernapasan", CDK, Volume 39 (1), 2012.

${ }^{4}$ Pasal 1 Angka 16 Undang-Undang Nomor 32 Tahun 2009 tentang Perlindungan dan Pengelolaan Lingkungan Hidup.

${ }^{5}$ Pasal 1 Angka 13 UUPLH.

${ }^{6}$ Pasal 1 Angka 7 UUPPLH.
} 
Mutu Gangguan; dan g) Baku Mutu lain sesuai dengan perkembangan ilmu pengetahuan dan teknologi. ${ }^{7}$ Jenis Baku Mutu Lingkungan Hidup menurut pasal 20 Ayat 2 seperti diatas dapat dibedakan dalam 2 sistem, yaitu: a) Effluent Standart merupakan kadar maksimum limbah yang diperbolehkan untuk dibuang ke lingkungan atau istilah dalam UUPPLH disebut Baku Mutu Air Limbah, Baku Mutu Emisi, dan Baku Mutu Gangguan. b ) Stream Standart merupakan batas kadar untuk sumber daya tertentu, seperti sungai, waduk dan danau. Kadar ditetapkan berdasarkan pada kemampuan sumber daya beserta sifat peruntukannya atau istilah dalam UUPPLH disebut Baku Mutu Air, Baku Mutu Udara Ambien dan Baku Mutu Air laut. ${ }^{8}$

Adanya 2 pembedaan Baku Mutu Lingkungan Hidup, maka konsep Pencemaran Lingkungan hidup adalah masuk atau dimasukkannya makhluk hidup, zat, energi dan/atau komponen lain ke dalam lingkungan hidup oleh kegiatan manusia, sehingga melampaui baku mutu lingkungan yang telah ditetapkan. ${ }^{9}$ Dengan definisi-definisi tadi, maka maksud dari pencemaran lingkungan hidup merupakan kegiatan yang melanggar effluent standart atau stream standart. Misalkan saja kita ambil contoh dalam Penerapan Baku Mutu Udara, PP No. 41 Tahun 1999 merupakan bentuk pengaturan yang mengimplementasikan ketentuan UUPPLH di bidang pengendalian pencemaran udara. "Dalam PP No. 41 Tahun 1999 telah diatur mengenai BMU ambien maupun emisi (gas buang) sesuai dengan "pesan yuridis" Pasal 14 UUPPLH: pengaturan baku mutu lingkungan (udara) dituangkan dalam Peraturan Pemerintah. ${ }^{10}$

Sebagai tindak lanjut Keputusan MENLH Nomor: KEP-45/MENLH/10/1997 ditetapkan Keputusan Kepala Badan Pengendalian Dampak Lingkungan Nomor. KEP107/Kabapeldal/II/1997 tentang Pedoman Teknis Perhitungan dan Pelaporan serta Informasi Indeks Standar Pencemar Udara, tanggal 21 November 1997 (Keputusan Kepala Bapedal Nomor: KEP-107/Kabapedal/II/1997. Pada Keputusan ini diketengahkan pengaruh setiap parameter pencemar udara dalam ISPU (Tabel 2).

Tabel 1: Kategori dan Rentang ISPU

\begin{tabular}{|c|c|l|}
\hline Kategori & Rentang & \multicolumn{1}{c|}{ Penjelasan } \\
\hline Baik & $0-50$ & $\begin{array}{l}\text { Tingkat kualitas udara yang tidak memberikan efek bagi } \\
\text { kesehatan manusia atau hewan dan tidak berpengaruh } \\
\text { pada tumbuhan, bangunan maupun nilai estetika }\end{array}$ \\
\hline Sedang & $51-100$ & $\begin{array}{l}\text { Tingkat kualitas udara yang tidak berpengaruh pada } \\
\text { kesehatan manusia ataupun hewan tetapi berpengaruh }\end{array}$ \\
\hline
\end{tabular}

\footnotetext{
${ }^{7}$ Pasal 20 Ayat 2 UUPPLH.

8 Lilik Pudjiastuti, "Instrumen Hukum Lingkungan Nasional: Perencanaan, Dokumen, Lingkungan dan Perizinan", Dalam Laode M. Syarif dan Andri G. Wibisana, Hukum Lingkungan: Teori, Legislasi dan Studi Kasus, Kemitraan Partnership, Jakarta: 2014, hlm. 133.

${ }^{9}$ Pasal 1 Angka 14 UUPPLH.

${ }^{10}$ Suparto Wijoyo, Refleksi Matarantai Pengaturan Hukum Pengelolaan Lingkungan Secara Terpadu (Studi Kasus Pencemaran Udara), Airlangga University Press, Surabaya: 2005, hlm. 425.
} 


\begin{tabular}{|c|c|l|}
\hline & & pada tumbuhan yang sensitive dan nilai estetika \\
\hline $\begin{array}{c}\text { Tidak } \\
\text { Sehat }\end{array}$ & $101-99$ & $\begin{array}{l}\text { Tingkat kualitas udara yang bersifat merugikan pada } \\
\text { manusia ataupun kelompok hewan yang sensitif atau bisa } \\
\text { menimbulkan kerusakan pada tumbuhan ataupun nilai } \\
\text { estetika }\end{array}$ \\
\hline $\begin{array}{c}\text { Sangat } \\
\text { Tidak } \\
\text { Sehat }\end{array}$ & $200-299$ & $\begin{array}{l}\text { Tingkat kualitas udara yang dapat merugikan kesehatan } \\
\text { pada sejumlah segmen populasi yang terpapar }\end{array}$ \\
\hline Berbahaya & $300-$ lebih & $\begin{array}{l}\text { Tingkat kualitas udara berbahaya yang secara umum } \\
\text { dapat merugikan kesehatan yang serius pada populasi }\end{array}$ \\
\hline
\end{tabular}

Sumber: Lampiran Keputusan Menteri Negara Lingkungan Hidup Nomor: KEP/45/MENLH/10/1997 tentang Indeks Standar Pencemar Udara. ${ }^{11}$

Tabel 2: Pengaruh Setiap Parameter Pencemar Udara Dalam ISPU

\begin{tabular}{|c|c|c|c|c|c|c|}
\hline Kategori & Rentang & $\begin{array}{c}\text { Karbon } \\
\text { Monoksi } \\
\text { da }(\mathrm{CO})\end{array}$ & $\begin{array}{c}\text { Nitrogen } \\
\text { Dioksida } \\
\left(\mathrm{NO}_{2}\right)\end{array}$ & Ozon $\left(\mathrm{O}_{3}\right)$ & $\begin{array}{c}\text { Sulfur } \\
\text { Dioksida } \\
\left(\mathrm{SO}_{2}\right)\end{array}$ & Partikulat \\
\hline Baik & $0-50$ & $\begin{array}{c}\text { Tidak } \\
\text { ada efek }\end{array}$ & $\begin{array}{l}\text { Sedikit } \\
\text { berbau }\end{array}$ & $\begin{array}{l}\text { Luka pada } \\
\text { beberapa } \\
\text { spesies } \\
\text { tumbuhan } \\
\text { akibat } \\
\text { kombinasi } \\
\text { dengan } \\
\mathrm{SO}_{2} \\
\text { (selama } 4 \\
\text { jam) }\end{array}$ & $\begin{array}{l}\text { Luka pada } \\
\text { beberapa } \\
\text { spesies } \\
\text { tumbuhan } \\
\text { akibat } \\
\text { kombinasi } \\
\text { dengan } \mathrm{O}_{3} \\
\text { (selama } 4 \\
\text { jam) }\end{array}$ & $\begin{array}{c}\text { Tidak ada } \\
\text { efek }\end{array}$ \\
\hline Sedang & $51-100$ & $\begin{array}{c}\text { Perubaha } \\
\text { n kimia } \\
\text { darah } \\
\text { tapi tidak } \\
\text { terdeteksi }\end{array}$ & Berbau & $\begin{array}{l}\text { Luka pada } \\
\text { beberapa } \\
\text { spesies } \\
\text { tumbuhan }\end{array}$ & $\begin{array}{l}\text { Luka pada } \\
\text { beberapa } \\
\text { spesies } \\
\text { tumbuhan }\end{array}$ & $\begin{array}{c}\text { Terjadi } \\
\text { penurunan } \\
\text { pada jarak } \\
\text { pandang }\end{array}$ \\
\hline $\begin{array}{l}\text { Tidak } \\
\text { Sehat }\end{array}$ & 101-199 & $\begin{array}{c}\text { Peningka } \\
\text { tan pada } \\
\text { kardio- }\end{array}$ & $\begin{array}{c}\text { Bau dan } \\
\text { kehilangan } \\
\text { warna. }\end{array}$ & $\begin{array}{c}\text { Penurunan } \\
\text { kemampua } \\
\text { n pada }\end{array}$ & $\begin{array}{c}\text { Bau } \\
\text { meningkatn } \\
\text { ya }\end{array}$ & $\begin{array}{c}\text { Jarak } \\
\text { pandang } \\
\text { turun dan }\end{array}$ \\
\hline
\end{tabular}

${ }^{11}$ Suparto Wijoyo, Refleksi Matarantai Pengaturan Hukum Pengelolaan Lingkungan Secara Terpadu (Studi Kasus Pencemaran Udara), Airlangga University Press, Surabaya: 2005, hlm. 429. Dikutip dari Lampiran Keputusan Menteri Negara Lingkungan Hidup Nomor: KEP/-45/MENLH/10/1997 tentang Indeks Standar Pencemar Udara. 


\begin{tabular}{|c|c|c|c|c|c|c|}
\hline & & $\begin{array}{l}\text { vskular } \\
\text { para } \\
\text { perokok } \\
\text { yang } \\
\text { sakit } \\
\text { jantung }\end{array}$ & $\begin{array}{l}\text { Peningkat } \\
\text { an } \\
\text { reaktivitas } \\
\text { pembulu } \\
\text { tenggorok } \\
\text { an pada } \\
\text { penderita } \\
\text { asma }\end{array}$ & $\begin{array}{c}\text { atlet yang } \\
\text { berlatih } \\
\text { keras }\end{array}$ & $\begin{array}{c}\text { kerusakan } \\
\text { tanaman }\end{array}$ & $\begin{array}{c}\text { terjadi } \\
\text { pengotora } \\
\text { n debu } \\
\text { dimana- } \\
\text { mana }\end{array}$ \\
\hline $\begin{array}{c}\text { Sangat } \\
\text { tidak } \\
\text { sehat }\end{array}$ & $200-299$ & $\begin{array}{c}\text { Meningk } \\
\text { at-nya } \\
\text { kardio- } \\
\text { vaskular } \\
\text { pada } \\
\text { orang } \\
\text { bukan } \\
\text { perokok } \\
\text { yang } \\
\text { berpenya } \\
\text { kit } \\
\text { jantung, } \\
\text { dan akan } \\
\text { tampak } \\
\text { beberapa } \\
\text { kelemaha } \\
\text { n yang } \\
\text { terlihat } \\
\text { secara } \\
\text { nyata }\end{array}$ & $\begin{array}{c}\text { Meningkat } \\
\text {-nya } \\
\text { sensitivita } \\
\text { s pasien } \\
\text { yang } \\
\text { berpenyak } \\
\text { it asma } \\
\text { dan } \\
\text { bronhitis }\end{array}$ & $\begin{array}{l}\text { Olah raga } \\
\text { ringan } \\
\text { mengakiba } \\
\text { t-kan } \\
\text { pengaruh } \\
\text { pernafasan } \\
\text { pada } \\
\text { pasien } \\
\text { yang } \\
\text { berpenyak } \\
\text { it paru- } \\
\text { paru } \\
\text { kronis }\end{array}$ & $\begin{array}{c}\text { Mening- } \\
\text { katnya } \\
\text { sensitivitas } \\
\text { pada pasien } \\
\text { berpenyakit } \\
\text { asma dan } \\
\text { bronhitis }\end{array}$ & $\begin{array}{c}\text { Meningka } \\
\text { t-nya } \\
\text { sensitivita } \\
\text { s pada } \\
\text { pasien } \\
\text { berpenya- } \\
\text { kit asma } \\
\text { dan } \\
\text { bronhitis }\end{array}$ \\
\hline $\begin{array}{c}\text { Ber- } \\
\text { bahaya }\end{array}$ & $\begin{array}{l}300- \\
\text { lebih }\end{array}$ & \multicolumn{5}{|c|}{ Tingkat yang berbahaya bagi semua populasi yang terpapar } \\
\hline
\end{tabular}

Sumber: Lampiran III Keputusan Kepala Badan Pengendalian Dampak Lingkungan Nomor: KEP-107/Kabapedal/II/1997 tentang Pedoman Teknis Perhitungan dan Pelaporan serta Informasi Indeks Standar Pencemar Udara. ${ }^{12}$

Ditelusuri lebih jauh krisis lingkungan ini disebabkan oleh kelemahan penegakan hukum yang ada, akar persoalannya karena masih kuatnya cara pandang atau paradigma ilmu pengetahuan modern yang bersifat "mekanistik-reduksionistik" dalam memandang

\footnotetext{
12 Suparto Wijoyo, Refleksi Matarantai Pengaturan Hukum Pengelolaan Lingkungan Secara Terpadu (Studi Kasus Pencemaran Udara), Airlangga University Press, Surabaya: 2005, hlm. 429-430, Dikutip dari Lampiran III Keputusan Kepala Badan Pengendalian Dampak Lingkungan Nomor: KEP-107/Kabapedal/II/1997 tentang Pedoman Teknis Perhitungan dan Pelaporan serta Informasi Indeks Standar Pencemar Udara.
} 
hubungan antara manusia dengan alam. ${ }^{13}$ Sifat mekanistik menunjukkan bahwa manusia dalam memandang seluruh alam semesta sebagai semacam mesin yang bekerja secara mekanik, bisa dianalisis dan diprediksi secara terpisah lepas dari keseluruhan yang membentuknya. Sifat tersebut membawa akibat yang semakin parah terhadap lingkungan, karena disertai pula dengan sifatnya yang reduksionistik. Melalui sifat yang reduksionistik itu, realitas di alam semesta direduksi dari satu aspek tanpa melihat keterkaitan yang lebih komperhensif dan holistik di antara berbagai aspek. ${ }^{14}$

Pendekatan "Mekanistik-reduksionistik" ini memandang hubungan antara manusia dengan lingkungan alam semesta secara terpisah dan menempatkan manusia di atas segalanya. Sikap dan perilaku eksploitatif tersebut dalam pandangan dan etika lingkungan disebut pandangan "antroposentrisme", yang menempatkan manusia dan kepentingannya sebagai pusat dari segalanya. Dominannya pandangan antroposentrisme inilah yang dalam sejarah telah melandasi ide Rene Descartes yang menyatakan bahwa tujuan ilmu adalah untuk mengusahakan posisi menguntungkan bagi manusia untuk menghadapi alam. ${ }^{15}$ Masalah perusakan lingkungan hidup merupakan persoalan kolektif yang membutuhkan partisipasi bersama dari semua komponen bangsa baik dari Presiden, penegak hukum hingga masyarakat secara keseluruhan, dan harus ada upaya serius untuk mengatasinya.

\section{b. Alasan Relevansi Perusakan Lingkungan Dipandang sebagai Tindak Pidana Terorisme}

Pemanfaatan terhadap lingkungan hidup seringkali merusak dan mencemari lingkungan hidup itu sendiri. Dewasa ini kerusakan lingkungan bukanlah merupakan kasus yang ganjil lagi. Kerusakan lingkungan terjadi dimana-mana dan menimbulkan berbagai dampak negatif bagi kelangsungan hidup manusia. Khususnya untuk generasi yang akan datang. Masyarakat akan selalu merasakan teror akibat dari perusakan lingkungan tersebut. Terlebih lagi, kerusakan lingkungan yang dibuat oleh oknumoknum yang tidak bertanggung jawab.

Siti Sundari Rangkuti mengatakan bahwa "hak atas lingkungan hidup yang baik dan sehat dilihat dari sudut dan bentuk dan isinya, formulasi hak ini bersifat hak asasi klasik, yang menghendaki penguasa menghindarkan diri dari campur tangan terhadap kebebasan individu untuk menikmati lingkungan hidupnya". ${ }^{16}$ Ditinjau dari bekerjanya, hak itu mengandung tuntutan yang bersifat hak sosial, karena sekaligus diimbangi dengan keharusan bagi pemerintah untuk menggariskan kebijaksanaan dan melakukan tindakan yang mendorong upaya ditingkatkannya upaya pelestarian lingkungan hidup.

13 A. Sonny Keraf, Etika Lingkungan, Buku Kompas, Jakarta: 2005, hlm. 253.

${ }^{14}$ Ibid.

15 Sudharto P Hadi dan Adji Samekto, Dimensi Lingkungan Dalam Bisnis, Kajian Tanggung Jawab Sosial Perusahaan Pada Lingkungan, Penerbit Undip, Semarang: 2007, hlm. 37.

16 Siti Sundari Rangkuti, Hukum Lingkungan dan Kebijaksanaan Nasional, Airlangga University Press, Surabaya: 2000, h. 171. 
Seperti yang dituangkan dalam Bab XA tentang Hak Asasi Manusia Perubahan Kedua UUD Negara Republik Indonesia Tahun 1945, Pasal 28H ayat (1) disebutkan, "Setiap orang berhak hidup sejahtera lahir dan batin, bertempat tinggal dan mendapatkan lingkungan hidup yang baik dan sehat serta berhak memperoleh pelayanan kesehatan". ${ }^{17}$

Dalam konteks gagasan yang memandang tindak pidana perusakan lingkungan sebagai kejahatan terorisme, maka menjadi keniscayaan untuk terlebih dahulu mengelaborasi esensi dari tindak pidana kejahatan terorisme tersebut. Untuk kemudian dilihat bagaimana relevansinya untuk disejajarkan dengan perusakan lingkungan. Dalam Undang-Undang Nomor 15 Tahun 2003 tentang Pemberantasan Tindak Pidana Terorisme, Bab I Ketentuan Umum, Pasal 1 ayat 1. Disebutkan bahwa Tindak Pidana Terorisme adalah segala perbuatan yang memenuhi unsur-unsur tindak pidana sesuai dengan ketentuan dalam undang-undang tersebut. Mengenai perbuatan apa saja yang dikategorikan ke dalam Tindak Pidana Terorisme, diatur dalam ketentuan pada Bab III (Tindak Pidana Terorisme), Pasal 6 dan Pasal 7. Selanjutnya dapat dilihat persamaan dari kedua variabel tersebut (perusakan lingkungan dan terorisme. Menarik untuk ditelaah bagaimana dalam pasal 10 Perpu Nomor 1 Tahun 2002 tentang Pemberantasan Tindak Pidana Terorisme yang disahkan menjadi Undang-Undang melalui UndangUndang No. 15 Tahun 2003, bahwa:

Dipidana dengan pidana yang sama dengan pidana sebagaimana dimaksud dalam pasal 6, setiap orang yang dengan sengaja menggunakan senjata kimia, senjata biologis, radiologi, mikroorganisme, radioaktif atau komponennya, sehingga menimbulkan susasana teror, atau rasa takut terhadap orang secara meluas, menimbulkan korban yang bersifat massal, membahayakan terhadap kesehatan, terjadi kekacauan terhadap kehidupan, keamanan dan hak-hak orang, atau terjadi kerusakan, kehancuran terhadap objek-objek vital strategis, lingkungan hidup, fasilitas publik, atau fasilitas internasional. ${ }^{18}$

Demikian pula ungkapan Pakar Hukum Lingkungan Suparto Wijoyo:

Dalam kasus lingkungan dapat pula diterapkan UU Terorisme yang tidak lain adalah Undang-Undang No. 15 Tahun 2003 tentang Pemberantasan Tindak Pidana Terorisme. UU Terorisme sejujurnya dapat diterapkan untuk melalukan proses hukum dalam kejahatan lingkungan (milieudelicten)". Dengan diundangkannya undang-undang ini maka lahirlah suatu terminologi

\footnotetext{
${ }^{17}$ Pasal 28H ayat (1)Bab XA tentang Hak Asasi Manusia Perubahan Kedua UUD Negara Republik Indonesia Tahun 1945.

${ }^{18}$ Pasal 10 Undang-Undang Nomor 15 Tahun 2003 tentang Penetapan Peraturan Pemerintah Pengganti UndangUndang Nomor 1 Tahun 2002 tentang Pemberantasan Tindak Pidana Terorisme.
} 
baru yang berupa kejahatan terorisme termasuk munculnya istilah saya berupa teroris lingkungan sebagai elaborasi tekstualnya. ${ }^{19}$

Pengaturan hukum di Indonesia terdapat dalam Undang-Undang Nomor 26 Tahun 2000 tentang "Pengadilan Hak Asasi Manusia". Kejahatan terhadap kemanusiaan sebagaimana dimaksud dalam Pasal 7 Huruf B adalah salah satu perbuatan yang dilakukan sebagai bagian dari serangan yang meluas atau sistematik yang diketahui bahwa serangan tersebut ditujukan secara langsung kepada penduduk sipil berupa: a) Pembunuhan; b) Pemusnahan; c) Perbudakan; d) Pengusiran atau pemindahan penduduk secara paksa; e) Perampasan kemerdekaan atau perampasan fisik secara sewenang-wenang yang melanggar (asas-asas) ketentuan pokok hukum internasional; f) Penyiksaan; g) Perkosaan, perbudakan seksual, pelacuran, pemaksaan kehamilan, pemandulan atau sterilisasi secara paksa atau bentuk-bentuk kekerasan seksual lain yang setara; h) Penganiayaan terhadap suatu kelompok tertentu atau perkumpulan yang disadari persamaan paham politik, ras, kebangsaan, etnis, budaya, agama, jenis kelamin atau alasan lain yang telah diakui secara universal sebagai hal yang dilarang menurut hukum internasional; i) Penghilangan orang secara paksa; j) Kejahatan apartheid. $^{20}$

Unsur-unsur Kejahatan Terhadap Kemanusiaan: a) Melakukan perbuatan yang diatur dalam Pasal 9 UU No.26 Tahun 2000 huruf (a) sampai dengan (j); b) Perbuatan yang dilakukan merupakan bagian dari serangan yang meluas dan sistematis; c) Diketahui bahwa serangan tersebut ditujukan pada penduduk sipil (perbuatan yang dilakukan sebagai kelanjutan dari kebijakan penguasa atau organisasi).

Membicarakan kejahatan terhadap kemanusiaan dalam konteks global dewasa ini menjadi relevan pula dengan membahas terorisme. Melalui European Convention on The Supression of Terrorism (ECST) tahun 1977 di Eropa, makna terorisme mengalami pergeseran dan perluasan paradigma, yaitu sebagai suatu perbuatan yang semula dikategorikan sebagai crimes against state (termasuk pembunuhan dan percobaan pembunuhan kepala negara atau anggota keluarganya), menjadi crimes against humanity, dimana yang menjadi korban adalah masyarakat sipil. Menurut Julia Lodge ada beberapa bentuk terorisme yang dikenal, "yang perlu kita bahas dari bentuk itu antara lain teror kriminal, dan teror politik. Kalau mengenai teror kriminal biasanya hanya untuk kepentingan pribadi atau memperkaya diri sendiri. Lain halnya dengan teror politik bahwasanya teror politik tidak memilih-milih korban". Teroris politik selalu siap melakukan pembunuhan terhadap orang-orang sipil: laki-laki, perempuan, dewasa, atau anak-anak dengan tanpa mempertimbangkan penilaian politik atau moral,

\footnotetext{
${ }^{19}$ Suparto Wijoyo, Teror Lingkungan, Kejahatan Lingkungan, Kejahatan Terorisme ?, http://supartowijoyofh.web.unair.ac.id/artikel-detail-154022-ENVIRONMENTAL\%20LAW-TEROR\%LINGKUNGAN.html, (Diakses pada tanggal 6/8/2016).

${ }^{20}$ Undang-Undang Nomor 26 Tahun 2000 tentang Pengadilan Hak Asasi Manusia.
} 
teror politik adalah suatu fenomena sosial yang penting. ${ }^{21}$ Tidak memperdulikan kepentingan negara dimana aksi teror itu dilaksanakan.

Menurut Loudewijk F. Paulus, ada yang perlu kita ingat bahwa ada jenis terorisme yang disebut dengan terorisme gaya baru, dari jenis ini mengandung beberapa karakteristik yaitu: a) Ada maksimalisasi korban secara sangat mengerikan; b) Keinginan untuk mendapatkan liputan di media massa secara International secepat mungkin; c) Tidak pernah ada yang membuat klaim terhadap terorisme yang sudah dilakukan; d) Serangan terorisme itu tidak pernah bisa diduga karena sasarannya sama dengan luasnya seluruh permukaan bumi. ${ }^{22}$

Transformasi konsep terorisme menjadi kejahatan kemanusiaan nampaknya dapat dielaborasi lebih jauh lagi relevansi dan keterkaitannya dengan tindak pidana lingkungan. Dalam Undang-Undang Nomor 32 Tahun 2009 tentang Perlindungan dan Pengelolaan Lingkungan Hidup, pengaturan pasal lebih banyak pasal sanksi pidananya bila dibandingkan dengan Undang-Undang Nomor 23 Tahun 1997 tentang Pengelolaan Lingkungan Hidup. Jika diamati dan dibandingkan pengaturan pasal tentang sanksi pidana terhadap tindak pidana lingkungan dalam UUPPLH lebih terperinci jenis tindak pidana lingkungan, misalnya ada ketentuan Baku Mutu Lingkungan Hidup (BMLH), diatur dalam pasal tersendiri tentang pemasukan limbah Bahan Berbahaya Dan Beracun (selanjutnya disingkat B3), masalah pembakaran lahan, dan penyusunan AMDAL tanpa sertifikat akan dikenakan sanksi pidana.

Tindak pidana yang diperkenalkan dalam UUPPLH juga dibagi dalam delik formil dan delik materil. Menurut Sukanda Husin delik materil dan delik formil dapat didefensikan sebagai berikut: a) Dellik materil (generic crime) adalah perbuatan melawan hukum yang menyebabkan pencemaran atau perusakan lingkungan hidup yang tidak perlu memerlukan pembuktian pelanggaran aturan-aturan hukum administrasi seperti izin. b) Delik formil (specific crime) adalah perbuatan yang melanggar hukum terhadap aturan-aturan hukum administrasi, jadi untuk pembuktian terjadinya delik formil tidak diperlukan pencemaran atau perusakan lingkungan hidup seperti delik materil, tetapi cukup dengan membuktikan pelanggaran hukum administrasi. $^{23}$

International Criminal Court (ICC) juga memperluas against humanity menjadi termasuk: a) Merusak Lingkungan; b) Eksploitasi sumber daya alam secara illegal; c) Pengambilalihan tanah secara illegal (land grabbing). ${ }^{24}$ Dari hal tersebut dapat diperkirakan bahwa kedepannya eksekutif perusahaan yang merusak lingkungan dapat

\footnotetext{
${ }^{21}$ Abdul Wahid, et. al, Kejahatan Terorisme Perspektif Agama, HAM dan Hukum, Refika Aditama, Bandung: 2004, hlm. 38.

${ }^{22}$ Ibid, hlm. 34.

${ }^{23}$ Sukanda Husin, Penegakan Hukum Lingkungan Indonesia, Sinar Grafika, Jakarta: 2009, hlm. 122.

$24 \mathrm{https}: / /$ www.theguardian.com/global/2016/sep/15/hague-court-widens-remit-to-include-environmentaldestruction-cases. (Diakses pada 10/10/2018)
} 
dijadikan tersangka di International Criminal Court (ICC). Melihat besarnya ancaman, ketakutan, dan horor akibat bencana lingkungan yang bersumber dari perusakan lingkungan hidup oleh manusia ini, maka tidak berlebihan untuk mengatakan, perbuatan dalam penciptaan ketakutan dan horor lingkungan itu dapat dikategorikan sebagai terorisme. Guna tercapainya komitmen dan tanggung jawab negara untuk menjamin penghormatan, perlindungan dan pemenuhan Hak atas Lingkungan Hidup sebagai Hak Asasi Manusia serta guna untuk mencapai sebuah tujuan Keadilan Lingkungan (environmental justice).

\section{c. Dinamika Kasus-kasus Lingkungan}

\section{1) Kasus PT. Freeport McMoran Indonesia}

Pertambangan PT. Freeport McMoran Indonesia (Freeport) di Papua yang dimulai sejak tahun 1967 hingga saat ini telah berlangsung selama 49 tahun. Selama ini, kegiatan bisnis dan ekonomi PT. Freeport McMoran Indonesia di Papua, telah mencetak keuntungan finansial yang sangat besar bagi perusahaan asing tersebut, namun belum memberikan manfaat optimal bagi negara, Papua, dan masyarakat lokal di sekitar wilayah pertambangan. Berbagai masalah, terutama dalam hal penerimaan negara yang tidak optimal, peran negara atau BUMN untuk ikut mengelola tambang yang sangat minim dan dampak lingkungan yang sangat signifikan, berupa rusaknya bentang alam pegunungan Grasberg dan Erstberg. PT. Freeport McMoran Indonesia memulai pertambangan terbuka di Etsberg, kawasan yang selesai ditambang pada tahun 1980-an dan menyisakan lubang sedalam 360 meter. Pada tahun 1988, PT. Freeport McMoran Indonesia mulai mengeruk cadangan raksasa lainnya, Grasberg, yang masih berlangsung hingga saat ini. Dari eksploitasi kedua wilayah ini, sekitar 7.3 juta ton tembaga dan 724.7 juta ton emas telah dikeruk. Pada Juli 2005, lubang tambang Grasberg telah mencapai diameter 2.4 kilometer pada daerah seluas 499 hektar dengan kedalaman $800 \mathrm{~m} 2 .{ }^{25}$

Disamping itu, di dalam tailing PT. Freeport McMoran Indonesia masih terdapat kandungan tembaga yang masih tinggi dan sangat beracun bagi kehidupan aquatic. Uji tingkat racun (toxicity) dan potensi peresapan biologis (bioavailability) oleh PT. Freeport McMoran Indonesia di daerah yang terkena dampak operasi tambang membuktikan bahwa sebagian besar tembaga terlarut dalam air sungai. Tembaga terlarut pada kisaran konsentrasi yang ditemukan di sungai Ajkwa bagian bawah mencapai tingkat racun kronis bagi $30 \%$ hingga $75 \%$ organism air tawar. Tak hanya berbahaya karena kandungan logam beratnya, jumlah tailing PT. Freeport McMoran Indonesia yang sangat masif juga memiliki bahaya yang sama. Hingga tahun 2005 tidak kurang dari 1 milyar ton tailing beracun dibuang PT.

\footnotetext{
25 Apit Moti, “Pertambangan PT. Freeport McMoran Indonesia dan Kerusakan Lingkungan”, dikutip dari http://apitmoti.blogspot.co.id/p/pertambangan-freeport-dan-kerusakan.html?m=1. (Diakses pada 2/8/2018).
} 
Freeport McMoran Indonesia ke sungai Aghawagon-Otomona-Ajkwa. ${ }^{26}$ Sebagaimana aktivitas tambang yang dilakukan sehingga banyak merugikan warga sekitar, dimana hal ini telah diatur dalam Undang-Undang No. 32 Tahun 2009 Tentang Perlindungan dan Pengelolaan Lingkungan Hidup Pasal 102, Freeport telah mengakibatkan kerusakan alam dan mengubah bentang alam serta mengakibatkan degradasi hutan yang seharusnya ditindak tegas pemerintah. Hal ini karena mengancam kelestarian lingkungan dan melanggar prinsip pembangunan berwawasan lingkungan yang diamanatkan UUD 1945 pasal 33 ayat (3) "Bumi dan air dan kekayaan alam yang terkandung di dalamnya dikuasai oleh Negara dan dipergunakan untuk sebesar-besarnya kemakmuran rakyat".

Kerusakan lingkungan yang begitu parah di daerah Papua tempat penambangan tembaga dan emas oleh PT. Freeport McMoran Indonesia membuat warga sekitar menjadi kesulitan untuk memenuhi kebutuhan hidupnya. Ironisnya kejadian ini telah terjadi sebelum undang-undang tentang pertambangan disahkan yang artinya juga terdapat lebih mengutamakan kepentingan pribadi dari pada kepentingan umum. Sehingga ketika undang-undang telah disahkan maka pemerintah tidak dapat untuk menindak lanjuti PT. Freeport McMoran Indonesia atas penambangannya di Papua. Tambang PT. Freeport McMoran Indonesia adalah bukti kesalahan pengurusan pada sektor pertambangan di Indonesia dan bukti tunduknya hukum dan wewenang negara terhadap korporasi. Tak hanya sebatas itu, pemerintah juga tidak pernah mampu mengontrol perusahaan pertambangan agar lebih bertanggung jawab.

\section{2) Kasus Luapan Lumpur PT. Lapindo Brantas}

Kasus Luapan Lumpur Lapindo Sidoarjo Surabaya, Jawa Timur yang terjadi pada tanggal 28 Mei 2006, disebabkan kebocoran gas hidrogen sulfida (H2S) di areal ladang eksplorasi gas Rig TMMJ, di lokasi Banjar Panji perusahaan PT. Lapindo Brantas (Lapindo) di Desa Ronokenongo, Kecamatan Porong, Kabupaten Sidoarjo. Semburan lumpur panas di kabupaten Sidoarjo sampai saat ini belum juga bisa teratasi. Semburan yang akhirnya membentuk kubangan lumpur panas ini telah memporak-porandakan sumber-sumber penghidupan warga setempat dan sekitarnya. $^{27}$ Tidak kurang 10 pabrik harus tutup, dimana 90 hektar sawah dan pemukiman penduduk tak bisa digunakan dan ditempati lagi. Berdasarkan data yang didapat WALHI Jawa Timur, yang mencatat jumlah pengungsi di lokasi Pasar Porong Baru sejumlah 1.110 Kepala Keluarga dengan Rincian 4345 jiwa dan 433 Balita, Lokasi Kedung Bendo jumlah pengungsi sebanyak 241 Kepala Keluarga

${ }^{26}$ Ibid.

${ }^{27}$ Kompas edisi Senin 19 Juni 2006, www.kompasianasharing.connecting, (Diakses pada 6/8/2018). 
yang terdiri dari 1.111 Jiwa dan 103 Balita, Lokasi Balai Desa Ronokenongo sejumlah 177 Kepala keluarga dengan rincian 660 jiwa. $^{28}$

Dalam upaya penyelidikan yang dilakukan oleh Komisi Nasional Hak Asasi Manusia (Komnas HAM) berdasarkan pasal 18-19 Undang-Undang No. 26 Tahun 2000 tentang Pengadilan Hak Asasi Manusia, yang merupakan pintu masuk atau inisiasi untuk membuka kasus-kasus yang terindikasi pelanggaran hak asasi manusia yang berat, juga akan mendapat kendala yang serupa. Misalnya, dalam suatu diskusi yang menghadirkan sejumlah ahli bidang hukum lingkungan dan hak asasi manusia bersama dengan para komisioner yang diselenggarakan Komnas HAM, memperbincangkan tentang apakah kasus Lumpur Lapindo di Sidoarjo sejak 2006 bisa didorong pada kategorisasi pelanggaran hak asasi manusia yang berat, khususnya kejahatan terhadap kemanusiaan. ${ }^{29}$ Syafrudin Ngulma, Komisioner Komnas HAM, pula berargumentasi tentang dampak kasus tersebut yang panjang dan terus terjadi hingga kini (continuing crimes and long term effects), baik dalam bentuk kerusakan atau kehilangan harta benda, hilangnya hak atas pekerjaan, pendidikan, kesehatan yang layak, hingga penderitaan mental dan tercerabutnya sistem sosial budaya setempat. Ironisnya, situasi penderitaan dan hilangnya hak-hak ekonomi, sosial dan budaya secara meluas tersebut disebabkan oleh suatu konspirasi kejahatan lingkungan dibalik bisnis pertambangan. ${ }^{30}$

Pengusaha Lapindo yang dianggap pihak yang paling bertanggung jawab atas terjadinya semburan Lumpur panas, karena ditengarai adanya penambangan yang tidak dilakukan sesuai aturan atau standar pengeboran, sehingga layak disebut sebagai bentuk kejahatan lingkungan (ecocide) dan ketidakpedulian terhadap ancaman atau bahaya pengeboran tersebut sehingga melahirkan kerusakan sistematik dan meluas atas segala hak-hak dasar rakyat, disebut sebagai kejahatan terhadap kemanusiaan yang dilakukan perusahaan (corporate crimes against humanity). ${ }^{31}$ Melalui Public Inquiry (pemberitahuan kepada masyarakat) terhadap pihak-pihak yang bertanggung jawab secara politik dan hukum untuk memberi ganti kerugian terhadap kasus Lumpur Lapindo tersebut. Namun pada Mahkamah

\footnotetext{
28 Ibid.

${ }^{29}$ Pertemuan para ahli bidang hukum lingkungan dan hak asasi manusia, Komnas HAM, Jakarta, 5 Desember 2007. Pada pertemuan tersebut dihadiri oleh sejumlah perwakilan organisasi non-pemerintah, antara lain: Lembaga Studi dan Advokasi Masyarakat (Elsam), Komisi untuk Orang Hilang dan Korban Tindak Kekerasan (KontraS) Jakarta, Wahana Lingkungan Hidup (Walhi), Indonesian Center for Environmental Law (ICEL), dan sejumlah individu yang kompeten dalam bidang hukum lingkungan dan hak asasi manusia. Dikutip dari R. Herlambang Perdana Wiratraman, "Konsep dan Pengaturan Hukum Kejahatan terhadap Kemanusiaan”, Jurnal Ilmu Hukum Yuridika, No.2, Vol.23, 2008.

${ }^{30}$ Akbar dan Al Azhar, Konspirasi di Balik Lumpur Lapindo, Dari Aktor hingga Strategi Kotor, Galangpress, Yogyakarta, 2007. Dikutip dari R. Herlambang Perdana Wiratraman, "Konsep dan Pengaturan Hukum Kejahatan terhadap Kemanusiaan”, Jurnal Ilmu Hukum Yuridika, No. 2, Vol. 2, 2008.

${ }^{31}$ R. Herlambang Perdana Wiratraman, "Konsep dan Pengaturan Hukum Kejahatan terhadap Kemanusiaan", Jurnal Ilmu Hukum Yuridika, No. 2, Vo. 23, 2008.
} 
Agung mengesahkan Perpres No 14/2007 dengan menafsir "jual-beli" tanah korban Lapindo sebagai bentuk "ganti-rugi". Tetapi, di sisi lain ternyata putusan MA No 2710 K/Pdt/2008 menyatakan Lapindo Brantas Inc. dan pemerintah tidak bersalah. Kasus tersebut menunjukkan dominasi korporasi atas negara. Etos kepemimpinan tegas dibutuhkan di negeri yang berbudaya hukum parokial dan subjektif ini.

\section{3) Kasus Kebakaran Hutan}

Kasus kebakaran hutan yang sudah lama melanda negeri ini sejak tahun 1982 hingga sampai pada puncaknya tahun 2015. Perlahan tapi pasti perusakan lingkungan dengan pembakaran hutan ini semakin parah, Pada tahun 2015 sebagian daerah di Indonesia dan sejumlah negara di Asia Tenggara diselimuti asap beracun selama berminggu-minggu. Kalimantan Tengah yang memiliki luas wilayah lebih dari 15,3 Juta hektar mempunyai masalah serius yaitu kerusakan hutan dan lahan yang telah mencapai lebih dari 4 juta hektar dan lahan kritis yang berada di dalam maupun di luar kawasan hutan seluas kurang lebih 1,7 juta hektar. ${ }^{32}$ Menurut data Kejadian Bencana Kebakaran Hutan dan Lahan dari Badan Nasional Penanggulangan Bencana (BNPB), Pada bulan Februari 2014 saja telah terjadi kebakaran hutan dan lahan di Kabupaten Bengkilis, Kabupaten Indragiri Hulu, Kabupaten Kampar, Kabupaten Kuansing, Kabupaten Pelalawan, Kabupaten Siak dan itu semua tersebar di Provinsi Riau. Pembakaran hutan dan lahan yang diakibatkan oleh oknum-oknum dari perusahaan yang ingin membuka lahan. Adapun korban pada saat iu, korban ISPA akibat asap yang ditimbulkan sebanyak 30.249 jiwa, Pneumonia 562 jiwa, Asma 1.109 jiwa, dan iritasi kulit sebanyak 1.490 jiwa. $^{33}$

Pada Desember 2015 pemerintah mengumumkan lebih dari 50 perusahaan akan dihukum atas peran mereka dalam melakukan pembakaran hutan. Penyelidikan lebih lanjut pun dilakukan saat itu. Namun sekitar 11 perusahaan yang diduga terlibat melakukan pembakaran hutan dan lahan di Provinsi Riau tersebut dan disidik oleh polisi, kini mendapat Surat Perintah Penghentian Penyidikan atau SP3. "Penghentian perkara 11 perusahaan pembakar lahan sangat mengecewakan rakyat Riau. Sangat tidak memberikan keadilan bagi 5 warga Riau yang meninggal terpapar asap kebakaran lahan perusahaan", kata Woro Supartinah, Koordinator Jikalahari, dalam wawancara dengan Media Tempo di Pekanbaru. ${ }^{34}$ Namun Polisi sebagai penegak hukum di negeri ini hanya mampu menuntaskan proses hukum dua perusahaan yakni PT. Langgam Inti Hibrido dan PT. Palm Lestari Makmur, 11 perusahaan lainnya justru dihentikan perkaranya, 5 perusahaan masih dalam proses penyelidikan, hanya dua perusahaan yang naik ke pengadilan, itu pun menjerat

\footnotetext{
${ }^{32}$ http://geospasial.bnpb.go.id/pantaubencana/data/datakbhutanall.php. (Diakses pada 6/82018)

${ }^{33}$ Ibid.

34 https://m.tempo.co/read/news/2016/07/19/063788803/11-kasus-kebakaran-hutan-di-sp3-polda-riau-dikecam. (Diakses pada 6/82018).
} 
perorangan, bukan korporasi. Dengan terbitnya surat SP3 oleh Polda Riau telah melanggar intruksi Presiden Republik Indonesia Joko Widodo yang meminta penegak hukum bertindak tegas pada pembakar lahan. Hal ini mengindikasikan lemahnya itikad Polda Riau dalam penegakan hukum kasus lingkungan hidup terutama kasus kebakaran lahan yang merusak lingkungan.

\section{d. Urgensi Perusakan Lingkungan Dipandang sebagai Tindak Pidana Terorisme}

\section{1) Krisis Penegakan Hukum Perusakan Lingkungan Hidup}

Krisis lingkungan tentu tidak cukup diselesaikan hanya secara teknis lingkungan semata, tetapi memerlukan perangkat hukum yang kuat dan pelaksanaannya secara efektif. Adapun yang menjadi persoalan ketika hukumnya itu sendiri yang mengalami krisis, dalam arti tidak mampu menjadi sarana pengintegrasi dan koordinasi proses-proses ekonomi, politik, dan budaya. enegakan hukum lingkungan adalah tahapan terakhir dalam rangkaian regulatory chain: "legislation", "regulation" "issueing permits", “implementation", dan "enforcement". 35 Terminologi "penegakan hukum lingkungan" dalam literatur hukum lingkungan berbahasa Inggris dikenal dengan istilah "environmental law enforcement" atau "enforcement of environmental law" dan pada kepustakaan Belanda disebut "handhaving van millieurecht". 36 Kata "penegakan hukum lingkungan" memiliki pengertian yang mengandung karakter keterpaduan lintas disiplin (ilmu) hukum. Definisi komprehensif tentang "penegakan hukum lingkungan" adalah:

Environmental law enforcement can be defined as the application of legal governmental power to ensure compliance with environmental regulation by means of: a) Administrative supervision of the compliance with environmental regulations (inspection) (=mainly preventive activity); b) Administrative measures or sanctions in case of non compliance (=corrective activity); c) Criminal investigation in case of presumed offences (=repressive activity); $d$ ) Criminal measures or sanctions in case of offences (=repressive activity); e)

\footnotetext{
${ }^{35}$ Rene Seerden and Michiel Heldeweg (editors), "Comparative Environmental Law in Europe: An Introduction to Public Environmental Law in the EU Member States" dalam G.H. Addink, Environmental Law in a Comparative Perspective: National, European, and International Law, Literature, Institute of Constitutional and Administratif Law, Utrecht University, Utrecht, 2002. h.61. Dikutip dari Suparto Wijoyo, Refleksi Matarantai Pengaturan Hukum Pengelolaan Lingkungan Secara Terpadu (Studi Kasus Pencemaran Udara), Airlangga University Press, Surabaya: 2005, hlm. 481.

${ }^{36}$ A.B. Blomberg, Integrale Handhaving van Milleurecht: een jurisdische studie over de handhaving van millieurecht in een democratische rechtstaat, Boom Juridische uitgevers, de Virje Universiteit te Amsterdam, 2000. Dikutip dari Suparto Wijoyo, Refleksi Matarantai Pengaturan Hukum Pengelolaan Lingkungan Secara Terpadu (Studi Kasus Pencemaran Udara), Airlangga University Press, Surabaya: 2005, hlm. 482.
} 
Civil action (law suit) in case of (threatening) non compliance (=preventive or corrective activity). ${ }^{37}$

Sehubungan dengan pengertian tersebut Siti Sundari Rangkuti menyatakan:

Dengan demikian, penegakan hukum lingkungan merupakan upaya untuk mencapai ketaatan terhadap peraturan dan persyaratan dalam ketentuan hukum yang berlaku secara umum dan individual, melalui pengawasan dan penerapan sanksi administrasi, kepidanaan dan keperdataan...., penegakan hukum lingkungan dapat dilakukan secara preventif dan represif, sesuai dengan sifat dan efektivitasnya. Penegakan hukum yang bersifat preventif berarti bahwa pengawasan aktif dilakukan terhadap kepatuhan terhadap peraturan tanpa kejadian langsung yang menyangkut peristiwa konkret yang menimbulkan sangkaan bahwa peraturan hukum telah dilanggar. Instrumen bagi penegakan hukum preventif adalah penyuluhan, pemantauan dan penggunaan kewenangan yang sifatnya pengawasan (pengambilan sampel .....) ..... Penegakan hukum yang bersifat represif dilakukan dalam hal perbuatan yang melanggar peraturan. Penindakan secara pidana umumnya selalu menyusul pelanggaran peraturan dan biasanya tidak dapat meniadakan akibat pelanggaran tersebut. Untuk menghindari penindakan pidana secara berulang-ulang pelaku (pencemar) sendiri yang harus menghentikan keadaan itu., 38

Dalam perspektif sistem hukum dalam artian yang luas tersebut, maka krisis hukum terjadi jika ketiga subsistem dari sistem hukum tersebut tidak bekerja atau berfungsi dengan baik. Betapapun baiknya aturan hukum, jika kelembagaan hukumnya tidak memiliki wewenang yang jelas dan aparatur penegak hukumnya tidak bekerja dengan baik (tidak memiliki kemampuan, moralitasnya bobrok, sarat $\mathrm{KKN}$, dan lain-lain), maka krisis hukum dan penegakan hukum niscaya tidak dapat dihindari. Sebagai contoh, hingga saat ini telah begitu banyak kelembagaan yang dibentuk di era reformasi, seperti Komisi Hukum Nasional (KHN), Komisi Yudisiil, Komisi Perlindungan Saksi, Komisi Ombudsman, Komisi Nasional Hak Asasi Manusia, Komisi Perlindungan Persaingan Usaha, dan masih puluhan lagi komisi independen lainnya.

Hal ini selain memberatkan negara (APBN), kenyataannya penegakan hukum masih karut-marut. Yang terjadi justru "persaingan kontra-produktif" antar lembaga, misalnya antara Komisi Yudisiil dengan Mahkamah Agung, antara Komisi Pemberantasan Korupsi (KPK) dengan Kepolisian dan Kejaksaan. Perilaku

\footnotetext{
${ }^{37}$ G.A. Biezeveld, Course on Environmental Law Enforcement, Syllabus, Surabaya: 1995, hlm.146. Dikutip dari Suparto Wijoyo, Ibid. h. 483.

${ }^{38}$ Siti Sundari Rangkuti, Hukum Lingkungan dan Kebijakan Lingkungan Nasional, Airlangga University Press, Surabaya: 2000, hlm. 209-210.
} 
dan moralitas aparat penegak hukum juga semakin memburuk. Banyaknya "Mafia Peradilan" dan judicial corruption yang melibatkan aparat penegak hukum yang terlibat kasus hukum, baik di kepolisian, kejaksaan, bahkan di lingkungan Mahkamah Agung (hakim).

Begitu banyaknya peraturan perundang-undangan yang dikeluarkan di era reformasi, tetapi nampaknya tidak dibuat melalui grand design yang komprehensif. Misalnya dibidang sumber daya alam, dikeluarkan Undang-Undang Nomor 19 Tahun 2004 tentang Perubahan atas Undang-Undang 41 Tahun 1999 tentang Kehutanan. Undang-undang ini dikeluarkan tidak terlepas dari tuntutan investor asing sebagai pemegang izin penambangan di dalam kawasan hutan lindung termasuk di PT. Freeport Indonesia. Selain itu, Undang-Undang Nomor 22 Tahun 2001 tentang Minyak dan Gas Bumi dan Undang-Undang Nomor 7 Tahun 2004 tentang Sumber Daya Air, secara substansional sangat liberal dan sarat dengan kepentingan asing yang mengatasnamakan "liberalisasi dan perdagangan bebas" dan ini sangat berpotensi merugikan kepentingan Indonesia. Hal inilah yang menjadi penyebab Undang-Undang Nomor 7 Tahun 2004 dinyatakan tidak berlaku lagi oleh Mahkamah Konstitusi. Untuk sementara, oleh Mahkamah Konstitusi dinyatakan berlaku kembali Undang-Undang Nomor 11 Tahun 1974 tentang Pengairan.

Sudah begitu banyak peraturan perundang-undangan tentang lingkungan hidup di Indonesia, baik dari instrumen hukum setingkat undang-undang, peraturan pemerintah pengganti undang-undang, peraturan presiden, peraturan menteri sampai ke tingkat peraturan daerah. Akan tetapi tetap saja proses penegakan hukum lingkungan masih jauh dari pencapaian perlindungan dan pemenuhan Hak atas Lingkungan Hidup sebagai Hak Asasi Manusia serta guna untuk mencapai sebuah tujuan keadilan lingkungan "environmental justice". Dibutuhkan langkah revolusioner dalam memandang tindak pidana perusakan lingkungan dalam rangka upaya mewujudkan keadilan lingkungan "environmental justice" tersebut.

\section{2) Prospek Pembaharuan Paradigma terhadap Kejahatan Lingkungan}

Penegakan hukum dibidang lingkungan menurut Keith Hawkin, sebagaimana dikutip oleh Koesnadi Hardjasoemantri bahwa "penegakan hukum lingkungan pada dasarnya dapat dilihat dari dua sistem atau strategi yang berkarakter pembenahan peraturan dan pemberian sanksi (sanctioning dengan penal style)". Oleh karena itu merupakan suatu keharusan dalam pengaturan mengenai lingkungan dimasukkan ketentuan pidana di dalamnya agar penegakan hukum lingkungan itu sendiri dapat berjalan secara efektif. Walaupun sanksi pidana telah dimasukkan, namun penegakan hukum dibidang lingkungan ini masih jauh dari pemenuhan hak asasi lingkungan dan keadilan lingkungan "environmental justice". Penegakan hukum lingkungan di Indonesia pada kenyataannya tidak menunjukan kecenderungan semakin membaik, bahkan yang terjadi malah sebaliknya. Kebijakan pertambangan 
di areal hutan lindung misalnya, justru melahirkan prinsip transgenetik yang mengabaikan prinsip kehati-hatian.

Ada 4 Hal yang dicermati oleh ICEL mengenai gagalnya penegakan hukum lingkungan di Indonesia, yaitu: a) Politik pembangunan ekonomi yang mengacu pada paradigma pertumbuhan (growth) dan ketiadaan komitmen untuk mewujudkan prinsip pembangunan berkelanjutan (good sustainable development governance), telah menyebabkan semakin terpuruknya penegakan hukum lingkungan dan melanggengkan proses eksploitasi sumber daya alam; b) Peraturan perundangundangan di bidang Pengelolaan Lingkungan yang telah ada tidak memiliki kemampuan untuk menjawab dan menyelesaikan permasalahan lemahnya penegakan hukum lingkungan serta eksploitasi sumber daya alam; c) Aparat penegak hukum tidak memiliki pengetahuan dan pemahaman serta keutuhan atau kesatuan yang cukup untuk menangani kasus-kasus lingkungan; d) Tidak adanya peran masyarakat dalam pengelolaan lingkungan dan rendahnya akses masyarakat terhadap keadilan sangat berpotensi terjadinya amuk massa dalam penyelesaian kasus lingkungan. ${ }^{39}$

Sebagai perbandingan terhadap konsepsi perusakan lingkungan dipandang sebagai tindak pidana terorisme menarik untuk dilihat bagaimana kasus yang terjadi pada saat konflik bersenjata internal di suriah dimulai pada bulan Maret 2011 diawali dengan tulisan yang terdapat dalam tembok sekolah bertuliskan "Rakyat Ingin Menumbangkan Rezim" yang menunjukan keinginan para kelompok oposisi untuk mengkudeta kepemimpinan Bashar Al-Assad sebagai Presiden. Kelompok oposisi menilai selama ini rezim Al-Assad adalah rezim yang otoriter dan juga penuh dengan tindakan korupsi seperti nepotisme. Selama perang saudara ini terjadi, banyak warga sipil netral ikut terbunuh oleh kelompok oposisi maupun pihak militer pro pemerintahan Al-Assad.

Menurut Sekretaris Jendral untuk urusan politik PBB, Lynn Pascoe, jumlah korban meninggal akibat dari konflik bersenjata internal di Suriah mencapai 7.500 orang. Pemerintah Suriah menyatakan kehilangan 1.345 pasukan keaman dan menyebut sebanyak 2.493 warga sipil yang tewas. ${ }^{40}$ Puncaknya ialah pada konflik bersenjata internal di Suriah tanggal 22 Agustus 2013 telah terjadi serangan senjata berupa roket pembawa hulu ledak tersebut mengandung zat "kimia" jenis Gas Sarin. ${ }^{41}$ Zat kimia tersebut terungkap setelah tim Pemantau Senjata Kimia PBB mengautopsi jenazah para korban yang terkena serangan langsung dari roket hulu ledak tersebut. Berdasarkan dari hasil sampel darah dan urin dari para korban yang

\footnotetext{
${ }^{39}$ Achmad Sentosa, Membentuk Pemerintahan Peduli Lingkungan dan Rakyat, ICEL, Jakarta: 2000, hlm. 7-10.

${ }^{40}$ Irdayanti, "Kebijakan Penolakan Rusia terhadap Strategi Barat di Suriah", Jurnal Transnasional, No. 1, Vol. 4, 2012, hlm. 2.

${ }^{41}$ Secretary General Report of CW Investigation, "Report on the Alleged Use of Chemical Weapons in the Ghouta Area of Damascus on 21 August 2013", www.un.org, (Diakses pada 10/8/2018)
} 
didapatkan dan diteliti oleh Tim Investigasi Senjata Kimia PBB terbukti bahwa senjata roket hulu ledak tersebut mengandung bahan kimia jenis Gas Sarin atau dikenal juga dengan senyawa organofosfat dengan rumus $[(\mathrm{CH} 3) 2 \mathrm{CHO}] \mathrm{CH} 3 \mathrm{P}(\mathrm{O}) \mathrm{F}^{42}$

Melihat kandungan dan dampak yang dikandung dan ditimbulkan oleh Gas Sarin atau dikenal juga dengan senyawa organofosfat dengan rumus [(CH3)2CHO $] \mathrm{CH} 3 \mathrm{P}(\mathrm{O}) \mathrm{F}$ maka menarik untuk dibandingkan dengan kandungan dengan dampak yang dihasilkan oleh perusakan lingkungan hidup dalam bentuk pembakaran hutan. Maka sudah sepantasnya tindak pidana perusakan lingkungan mendapatkan ganjaran yang sepadan dengan kejahatan tindak pidana terorisme. Bilamana dalam kejahatan tindak pidana terorisme di terapkan hukuman mati maka sudah sepantasnya juga dalam kasus tindak pidana perusakan lingkungan dapat juga dikenai hukuman mati atau dijatuhi pidana seumur hidup.

Pemikiran yang dikemukakan ini diharapkan pula dapat mengungkapkan unsur-unsur yang berperan dalam pengembangan Hukum Lingkungan serta melahirkan konsepsi baru bagi penyempurnaan kebijakan hukum lingkungan yang sedang dilaksanakan atau dirumuskan pemerintah. Sehubungan dengan hal ini, dihasilkan konsep pemikiran dan alternatif kebijakan ini dapat berguna untuk penindakan para pelaku perusakan lingkungan hidup yang telah merajalela dan untuk tercapainya keadilan lingkungan (environmental justice). Terlebih lagi perlu disadari bahwa kebutuhan terhadap aturan yang benar-benar dapat membuat para pelaku perusakan lingkungan mendapatkan rasa jera benar-benar urgent, oleh karena kerugian yang diperoleh manusia itu sendiri.

\section{3) Implementasi Konsep Perusakan Lingkungan Dipandang sebagai Tindak Pidana Terorisme}

Secara konseptual, implementasi perusakan lingkungan dipandang sebagai tindak pidana terorisme sangat perlu sebagai acuan dalam penegakan hukum lingkungan nantinya di Indonesia. Jika kita melihat di dalam pembahasan kasuskasus di sub bab sebelumnya seperti kasus pertambangan PT. Freeport McMoran Indonesia (Freeport) di Papua, kasus lumpur lapindo oleh PT. Lapindo Brantas (Lapindo) di Desa Ronokenongo, Kecamatan Porong, Kabupaten Sidoarjo, dan kasus pembakaran hutan di Riau oleh beberapa perusahaan, hampir semua penyelesaian kasus tersebut kandas di tengah pengadilan dan tidak jelas penyelesaiannya. Bahkan jika prosesnya selesai putusan pengadilan tidak ada yang mempertimbangkan aspek hak asasi manusia, hak asasi lingkungan dan jauh dari kata keadilan untuk lingkungan (environmental justice).

42 Ibid. 
Dengan adanya konsep ini semoga cita-cita bangsa, tujuan negara dan cita hukum dapat terpenuhi sesuai dengan tujuan perlindungan dan pengelolaan lingkungan hidup di Indonesia sebagai berikut: a) Melindungi wilayah kesatuan Republik Indonesia dari pencemaran dan/atau kerusakan lingkungan hidup; b) Menjamin keselamatan, kesehatan, dan kehidupan manusia; c) Menjamin kelangsungan kehidupan makhluk hidup dan kelestarian ekosistem; d) Menjaga kelestarian, keselarasan, dan keseimbangan lingkungan hidup; e) Mencapai keserasian, keselarasan, dan keseimbangan lingkungan hidup; f) Menjamin terpenuhinya keadilan generasi masa kini dan generasi masa depan; g) Menjamin pemenuhan dan perlindungan hak atas lingkungan hidup sebagai bagian dari hak asasi manusia; h) Mengendalikan pemanfaatan sumber daya alam secara bijaksana; i) Mewujudkan pembangunan berkelanjutan; dan j) Untuk mengantisipasi isu lingkungan global.

Sebagaimana tujuan UUPPLH untuk menjamin pemenuhan dan perlindungan hak atas lingkungan hidup sebagai bagian dari hak asasi manusia maka dengan diterapkannya konsep ini maka harapannya konsep tindak pidana perusakan lingkungan dipandang sebagai tindak pidana terorisme ini bisa menegakan penindakan hukum lingkungan sesuai dengan tujuan UUPPLH. Adapun juga harapan dengan adanya konsep tindak pidana perusakan lingkungan dipandang sebagai tindak pidana terorisme ini bisa menjamin keselamatan, kesehatan, kehidupan manusia dan sumber daya alam, agar generasi yang akan datang juga tetap masih bisa menikmati anugrah Rahmat Tuhan YME yaitu sumber daya alam beserta ekosistemnya ini.

Diharapkan dengan konsep perusakan lingkungan dipandang sebagai tindak pidana terorisme dapat membantu penindakan masalah kerusakan lingkungan hidup akibat perusakan lingkungan, kemiskinan struktural seharusnya dilihat sebagai masalah tindak pidana terorisme dan pelanggaran Hak Asasi manusia. Yang penyelesaiannya dibutuhkan komitmen dan tanggung jawab negara untuk menjamin penghormatan, perlindungan dan pemenuhan Hak atas Lingkungan Hidup sebagai Hak Asasi Manusia serta guna untuk mencapai sebuah tujuan Keadilan Lingkungan (environmental justice).

\section{PENUTUP}

Berdasarkan pembahasan yang telah dikemukakan pada bab sebelumnya dapat dikemukakan kesimpulan sebagai berikut: 1) Meningkatnya tindakan perusakan lingkungan di Indonesia telah memberikan dampak yang sangat buruk bagi kehidupan saat ini maupun masa depan. Mengenai konsepsi yang memandang pelaku perusakan lingkungan sebagai terorisme 
merupakan elaborasi tekstual sebagaimana yang termaktub di dalam ketentuan Pasal 10 Undang-Undang Nomor 15 Tahun 2003 tentang Pemberantasan Tindak Pidana Terorisme. Berdasarkan hal ini diharapkan dapat tercapainya komitmen dan tanggung jawab negara untuk menjamin penghormatan, perlindungan, pemenuhan Hak atas Lingkungan Hidup dan Hak Asasi Manusia serta guna untuk mencapai sebuah tujuan Keadilan Lingkungan (environmental justice); 2) Tindak Pidana Perusakan Lingkungan yang dapat dikategorikan sebagai bentuk terorisme adalah yang memenuhi kualifikasi sebagai berikut: Perusakan dan pencemaran lingkungan yang dampaknya telah melampaui Baku Mutu Lingkungan Hidup (BMLH), terjadi pelepasan zat kimia beracun ke ruang publik (seperti yang terjadi pada saat konflik bersenjata internal di suriah pada bulan Maret 2011), menimbulkan korban secara massal, dan menyebabkan kerusakan dan kehancuran terhadap objek-objek vital yang strategis. Dimana semua kesamaan kriteria tersebut menjadikan tindak pidana perusakan lingkungan menjadi sejajar dengan tindak pidana terorisme dengan sama-sama menyandang predikat sebagai kejahatan terhadap kemanusiaan; 3) Perusakan lingkungan yang dilakukan oleh pihak perusahaan atau industri mengalami peningkatan dikarenakan masih rendahnya ketaatan dan kepatuhan serta kesadaran warga masyarakat untuk menjaga lingkungan, sehingga hal ini dapat menjadi indikator bahwa penegakan hukum terhadap perlindungan dan pengelolaan lingkungan hidup belum berjalan. Dengan demikian implementasi UndangUndang Nomor 32 Tahun 2009 tentang Perlindungan dan Pengelolaan Lingkungan Hidup masih rendah, hal ini dikarenakan penegakan hukum terutama dalam masalah pembuktian sulit dilakukan dan pengawasan dalam rangka pengendalian dan pengelolaan lingkungan hidup masih jalan ditempat.

\section{DAFTAR PUSTAKA}

\section{Buku}

A. Sonny Keraf, Etika Lingkungan, Buku Kompas, Jakarta: 2005.

Abdul Wahid, et. al, Kejahatan Terorisme Perspektif Agama, HAM dan Hukum, Refika Aditama, Bandung: 2004

Achmad Sentosa, Membentuk Pemerintahan Peduli Lingkungan dan Rakyat, ICEL, Jakarta: 2000.

Laode M. Syarif dan Andri G. Wibisana, Hukum Lingkungan: Teori, Legislasi dan Studi Kasus, Kemitraan Partnership, Jakarta: 2014.

Siti Sundari Rangkuti, Hukum Lingkungan dan Kebijakan Lingkungan Nasional, Airlangga University Press, Surabaya: 2000.

Siti Sundari Rangkuti, Hukum Lingkungan dan Kebijaksanaan Nasional, Airlangga University Press, Surabaya: 2000. 
Sodikin, Penegakan Hukum Lingkungan Tinjauan Atas Undang-Undang Nomor 23 Tahun 1997, Djembatan, Jakarta: 2003.

Sudharto P Hadi dan Adji Samekto, Dimensi Lingkungan Dalam Bisnis, Kajian Tanggung Jawab Sosial Perusahaan Pada Lingkungan, Penerbit Undip, Semarang: 2007.

Sukanda Husin, Penegakan Hukum Lingkungan Indonesia, Sinar Grafika, Jakarta: 2009.

Suparto Wijoyo, Refleksi Matarantai Pengaturan Hukum Pengelolaan Lingkungan Secara Terpadu (Studi Kasus Pencemaran Udara), Airlangga University Press, Surabaya: 2005.

Suparto Wijoyo, Refleksi Matarantai Pengaturan Hukum Pengelolaan Lingkungan Secara Terpadu (Studi Kasus Pencemaran Udara), Airlangga University Press, Surabaya: 2005.

\section{Jurnal/Artikel Prosiding}

Fikri Faisal,et.al, “Dampak Asap Kebakaran Hutan pada Pernapasan”, CDK, Volume 39 (1), 2012.

Irdayanti, "Kebijakan Penolakan Rusia terhadap Strategi Barat di Suriah", Jurnal Transnasional, No. 1, Vol. .4, 2012.

R. Herlambang Perdana Wiratraman, "Konsep dan Pengaturan Hukum Kejahatan terhadap Kemanusiaan”, Jurnal Ilmu Hukum Yuridika, No. 2, Vo. 23, 2008.

\section{Peraturan Perundang-undangan}

Undang-undang Dasar Negara Republik Indonesia Tahun 1945

Undang-Undang Nomor 32 Tahun 2009 tentang Perlindungan dan Pengelolaan Lingkungan Hidup

Undang-Undang Nomor 15 Tahun 2003 tentang Penetapan Peraturan Pemerintah Pengganti Undang-Undang Nomor 1 Tahun 2002 tentang Pemberantasan Tindak Pidana Terorisme.

Undang-Undang Nomor 26 Tahun 2000 tentang Pengadilan Hak Asasi Manusia.

\section{Sumber Lainnya}

http://geospasial.bnpb.go.id/pantaubencana/data/datakbhutanall.php. (Diakses pada 6/82018) https://m.tempo.co/read/news/2016/07/19/063788803/11-kasus-kebakaran-hutan-di-sp3polda-riau-dikecam. (Diakses pada 6/82018). 
https://www.theguardian.com/global/2016/sep/15/hague-court-widens-remit-to-includeenvironmental-destruction-cases. (Diakses pada 10/10/2018)

Kompas edisi Senin 19 Juni 2006, www.kompasianasharing.connecting, (Diakses pada 6/8/2018).

Lampiran III Keputusan Kepala Badan Pengendalian Dampak Lingkungan Nomor: KEP107/Kabapedal/II/1997 tentang Pedoman Teknis Perhitungan dan Pelaporan serta Informasi Indeks Standar Pencemar Udara.

Secretary General Report of CW Investigation, "Report on the Alleged Use of Chemical Weapons in the Ghouta Area of Damascus on 21 August 2013", www.un.org, (Diakses pada $10 / 8 / 2018)$

Suparto Wijoyo, Teror Lingkungan, Kejahatan Lingkungan, Kejahatan Terorisme?, http://supartowijoyo-fh.web.unair.ac.id/artikel-detail-154022-

ENVIRONMENTAL\%20LAW-TEROR\%LINGKUNGAN.html, (Diakses pada tanggal 6/8/2016). 